\title{
MORTALITY IN FOURTEENTH-CENTURY EXETER
}

\author{
by
}

\section{NICHOLAS ORME*}

For many years, pioneer work has begun to uncover the history of mortality in England during the thirteenth and early fourteenth centuries, before the Black Death. Nearly a hundred years ago, Creighton collected chronicle references to outbreaks of disease and mortality in his History of epidemics in England. ${ }^{1}$ In 1948 and 1966, J. C. Russell analysed the inquisitions post mortem to reveal patterns of death among the feudal land-holding aristocracy. ${ }^{2}$ In 1959, M. M. Postan and J. Titow showed how manorial records could yield statistics of heriots (death duties) between 1245 and 1350, and how the annual fluctuations of such heriots could be compared with (and sometimes related to) the price and availability of corn. ${ }^{3}$ In 1973, I. Kershaw developed this technique into a deeper study of 'The agrarian crisis in England, 1315-1322', demonstrating how poor harvests and animal diseases led to starvation and epidemics among humans, which reached a peak in $1316-17 .{ }^{4}$ Most of the evidence so far assembled relates to annual rather than seasonal mortality. Chroniclers chiefly note occasional spectacular crises, heriots cannot easily be translated into precise death dates, and wills, which have been used to estimate seasonal mortality in the fifteenth century, do not exist in significant numbers before the middle of the fourteenth. ${ }^{5}$ The best early evidence for seasonal mortality is that which Russell has deduced for the aristocracy from the inquisitions post mortem.

The medieval archives of Exeter Cathedral contain two series of records which modestly increase our knowledge of seasonal mortality in the early fourteenth century. The obit accounts, which survive from Midsummer 1305 to Michaelmas 1467, are records of monetary offerings in the cathedral (made at Whitsuntide, at funerals, and in the public collecting boxes) and certain payments to the cathedral clergy (notably for attending the obit masses held on the anniversaries of people's deaths). ${ }^{6}$ It is the funeral

*Nicholas Orme, DPhil, DLitt, Department of History and Archaeology, University of Exeter, Queen's Building, The Queen's Drive, Exeter EX4 4QH

${ }^{1}$ C. Creighton, A history of epidemics in England, 2nd ed., 2 vols., London, Frank Cass, 1965.

2 J.C. Russell, Britishmedievalpopulation, Albuquerque, University of New MexicoPress, 1948,pp.194-234; 'The preplague population of England', J. British Studies, 1966, 5 no.2: 1-21.

${ }^{3}$ M. M. Postan and J. Titow, 'Heriots and prices on Winchester manors', Econ. Hist. Rev., 2nd series, 1958-9, 11: 392-417.

${ }^{4}$ I. Kershaw, 'The agrarian crisis in England, 1315-1322', Past and Present, 1973, 59: 3-50.

${ }^{5}$ For a recent review of this topic, see J. Hatcher, 'Mortality in the fifteenth century: some new evidence', Econ. Hist. Rev., 2nd series, 1986, 39: 19-22.

${ }^{6}$ Exeter Cathedral Archives, Dean and Chapter (hereinafter D \& C), 3673, 3764-3772. Only the first two numbers are relevant to this article. 


\section{N. Orme}

offerings with which we shall be concerned: "passage money" or passagium, as the term was at Exeter. ${ }^{7}$ They appear frequently in the obit accounts between 1305 and about 1327, after which they disappear, so that their importance is roughly confined to the reign of Edward II. The other records are the accounts of the small hospital of Clyst Gabriel at Bishop's Clyst, four miles east of Exeter, which was founded by Bishop Stapledon of Exeter in 1309-12 for the maintenance of two able-bodied chantry priests and twelve infirm priests who could no longer do ecclesiastical work. ${ }^{8}$ The hospital was supervised by the cathedral, which paid quarterly sums to one of the chantry priests, and he doled it out in weekly payments to each of the infirm priests. The chantry priest was required to produce an annual account of his disbursements, and in this he recorded the names of the infirm priests and the dates of their arrivals and departures through death or withdrawal. From January 1312 until Michaelmas 1350, there is a good surviving series of these accounts, covering thirty-two out of the thirty-nine financial years and preserving most of the names of the infirm priests. ${ }^{9}$ Clyst Gabriel possesses, in effect, one of the earliest surviving registers of the inmates of an English hospital.

Funeral offerings have a special significance at Exeter. From Anglo-Saxon times the cathedral cemetery was the principal burial ground of the city, ${ }^{10}$ and by the twelfth century, the cathedral authorities had legally established that no other burial grounds should exist or burials take place without its permission. ${ }^{11}$ In consequence, the parish churches of Exeter did not possess their own churchyards for burial in the middle ages, although as time went on three monasteries, two friaries, and a hospital in or near the city were allowed to have burial grounds and hold funerals for their own clergy. Lay people could apply to the cathedral for permission to be buried in parish churches, religious houses or their burial grounds, but no exception was made for anyone other than the clergy of the religious houses to have a funeral away from the cathedral. ${ }^{12}$ This was because of the valuable perquisites forthcoming from funeral dues and offerings. In 1301, just four years before the obit accounts begin, the cathedral authorities took drastic action to prevent the funeral of a layman in another church. Two canons personally led a band of men in seizing the body of Sir Henry de Ralegh, a local knight, from the Dominican friary where he had died wearing the friars' habit, and took it back to the cathedral for the funeral. ${ }^{13}$ As late as the sixteenth century, the cathedral still claimed the monopoly of funerals, and even permission to be buried elsewhere required lengthy and wearisome negotiations with the dean and chapter. ${ }^{14}$

\footnotetext{
${ }^{7}$ The use of the word in this sense seems peculiar to Exeter.

${ }^{8}$ On the history of the hospital, see N. I. Orme, 'A medieval almshouse for the clergy: Clyst Gabriel Hospital near Exeter', J. Ecclesiastical History, forthcoming.

${ }^{9} \mathrm{D} \&$ \& $792-797 / 3$ (some of these accounts are damaged and not normally available); 5206-5215.

${ }^{10}$ C. G. Henderson and P. T. Bidwell, 'The Saxon Minster at Exeter', Susan M. Pearce (editor), The early church in western Britain and Ireland, Oxford B.A.R., 1982, pp.145-175.

${ }^{11}$ D \& C 1374, 2074; F. C. Hingeston-Randolph (editor), The register of Walter Bronescombe, Bishop of Exeter, London and Exeter, 1889, p.290.

12 E.g., in 1389 the dean and chapter granted permission for a burial away from itscemetery only "after mass had been said [in the cathedral] as the custom is, and due offerings made" (D \& C $3550 \mathrm{f} \mathrm{57).}$

${ }^{13} \mathrm{On}$ this affair, see A. G. Little and R. C. Easterling, The Franciscans and Dominicans of Exeter, Exeter, 1927, pp.40-45.

14 John Hooker, The description of the citie of Excester, part 2, W. J. Harte et al.(editors), Exeter, Devon and Cornwall Record Society, 1919, pp.213, 216.
} 


\section{Mortality in fourteenth-century Exeter}

Almost all Exeter funerals, then, were supposed to be held in the cathedral, but they were not all mentioned in the obit accounts. To qualify for mention, there had to be sufficient offerings of money at the funeral to leave a residue after certain unknown deductions had been made (such as to pay the clergy who officiated). This residue was then recorded in the accounts, because it had to be divided equally among the canons in residence. If the residue was more than $8 d$., the clerk entered it as a separate item, since there were usually about sixteen residential canons and each could then be given at least $\frac{1}{2} d .^{15}$ In about a third of the entries, the clerk recorded the name of the dead person-man, woman, or child-but most often he simply noted that the "passagium for a certain corpse, deductions being deducted" was such and such. If the residue was less than $8 d$., the sum was too small to divide, and it was held over until similar small amounts had accumulated. The total sum was then recorded in the accounts as "passagium for certain corpses", without explaining how many were involved.

The obit accounts, therefore, when they are well kept, appear to provide us with a complete list of funerals producing residual offerings of over $8 d$., an approximate idea of the occurrence of funerals with smaller residues, and no record of funerals without any residues. As the largest number of entries in one year comprises only thirty-eight individuals and twenty-three groups in 1316, it is unlikely that the accounts contain a full record of the funerals that must have taken place each year in a city of at least 4,000 people. ${ }^{16}$ An analysis of the 144 cases between 1305 and 1327 in which the name of the dead person is recorded shows that sixty-seven adult laymen were mentioned, thirty-five male clergy, thirty-one adult laywomen, and eleven children. The laymen were mainly prosperous tradesmen and craftsmen of the city, but their children, wives, and the poor were wholly or partly unrepresented. In view of this, the obit statistics should probably be regarded as confined to the wealthier adult men of Exeter and a few of their wives.

The obit clerk divided his accounting year, and hence the record of funerals, into four terms beginning at Christmas (25 December), Easter Day, Midsummer Day (24 June), and Michaelmas Day (29 September). The Midsummer and Michaelmas terms were always the same length, but the Christmas and Easter terms were variable, depending on the date of Easter (which fell between 23 March and 19 April in the early fourteenth century). Provided we make allowances for this, it is possible to divide the funeral statistics into four seasons and to glimpse something of the seasonal variations of mortality among the élite of the city. In theory, it should be possible even to subdivide the terms into months, because the accounts are kept in calendar order, funeral offerings being scattered among the obits (many of whose dates are known). Unfortunately, the calendars are virtually impossible to unravel. The obits are often

\footnotetext{
${ }^{15}$ On the number of canons, see Audrey M. Erskine, 'The medieval financial records of the Cathedral Church of Exeter', J. Soc. Archivists, 1962, 2 part 6: 254-266.

${ }_{16}$ In $1377,1,560$ people paid the poll-tax (Russell, op.cit., note 2 above, p. 142), which seems low compared with similar towns. Maryanne Kowaleski, 'The commercial dominance of a medieval provincial oligarchy: Exeter in the late fourteenth century', Mediaeval Studies, 1984, 46: 356, converts this to "about 3,000". If a forty per cent decline is assumed during the fourteenth century, as R. S. Gottfried suggests for Bury $S t$ Edmunds and the urban crisis, 1290-1539, Princeton University Press, 1982, pp.51-52, this would indicate about 4,200 in the 1310 s and 20 s. But the size, density of settlement, prosperity, and importance of the city imply a higher number.
} 


\section{N. Orme}

listed out of order (depending on when they were paid for, rather than when they were held), they do not provide a dating system easily translated into months, and funerals tend to increase towards the end of certain terms, as if the clerk was trying to clear up arrears before he closed his account. It is safer to work with the clerk's own unit of the term, in which case funerals can probably be trusted to have happened in the term under which they are entered. The accompanying Table 1 is constructed accordingly.

TABLE 1. RECORDED FUNERALS AT EXETER CATHEDRAL, 1305-1327

(First figures $=$ single funerals; second figures $=$ groups of funerals)

$\begin{array}{lllllll}\text { Year } & \begin{array}{l}\text { Date of } \\ \text { Easter }\end{array} & \text { Christmas } & \text { Easter } & \text { Midsummer } & \text { Michaelmas } & \text { Total } \\ & & & & & & \\ 1305 & 18 \mathrm{Apr} & \text { missing } & \text { missing } & 6+1 & 5 & \\ 1306 & 13 \mathrm{Apr} & 9+1 & 2+6 & 7+1 & 2+2 & 20+10 \\ 1307 & 26 \mathrm{March} & 5 & 7+1 & 9+3 & 7+3 & 28+7 \\ 1308 & 14 \mathrm{Apr} & 7 & 8+1 & 6+4 & 4+3 & 25+8 \\ 1309 & 30 \mathrm{March} & 9 & 8+1 & 5+1 & 6 & 28+2 \\ 1310 & 19 \mathrm{Apr} & 2 & 5+1 & 4 & 4+1 & 15+2 \\ 1311 & 11 \mathrm{Apr} & 6+2 & 2+1 & 4+2 & 7+3 & 19+8 \\ 1312 & 26 \mathrm{March} & 6 & 8+3 & 15+1 & 9 & 38+4 \\ 1313 & 15 \mathrm{Apr} & \text { missing } & 7+5 & 6+2 & 5+2 & \\ 1314 & 7 \mathrm{Apr} & 10+1 & 7+1 & 5+5 & 4+1 & 26+8 \\ 1315 & 23 \mathrm{March} & 11+4 & 7+1 & 6+4 & 7+2 & 31+11 \\ 1316 & 11 \mathrm{Apr} & 7 & 7 & 15+19 & 9+4 & 38+23 \\ 1317 & 3 \mathrm{Apr} & 4+5 & 2+6 & 4+15 & \text { missing } & \\ 1320 & 30 \mathrm{March} & \text { missing } & \text { missing } & 14 & 2 & \\ 1321 & 19 \mathrm{Apr} & 0 & 0 & 7+1 & 6 & 13+1 \\ 1322 & 11 \mathrm{Apr} & 4 & 5+1 & 1 & 4+2 & 14+3 \\ 1323 & 27 \mathrm{March} & 4+1 & 6+1 & 4+2 & 8+3 & 22+7 \\ 1324 & 15 \mathrm{Apr} & 5 & 5 & 4+2 & 3 & 17+2 \\ 1325 & 7 \mathrm{Apr} & 0 & 0 & 1 & 3 & 4 \\ 1326 & 23 \mathrm{March} & 2+1 & 0 & 4 & 5 & 11+1 \\ 1327 & 12 \mathrm{Apr} & 1 & 8 & 13+3 & 4 & 26+3\end{array}$

Crude total when all four terms survive:

$$
88+10 \quad 85+18 \quad 110+48 \quad 92+24
$$

Total, fixing Easter at 25 March, when all four terms survive:

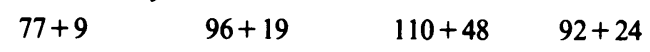

The accounts contain the fullest record of funerals from Midsummer 1305 to Michaelmas 1317, after which there is a gap of nearly three years. When they resume at Midsummer 1320, they are less reliable, omitting funeral offerings from whole terms, and after 1327, offerings appear so rarely that it ceases to be worth considering them. In the period up to 1327, we see that when all four terms are recorded, and allowing for the Easter variations, the term with most funerals in the year was Christmas on two occasions, Easter three times, Michaelmas five times, and Midsummer seven times. Midsummer was also a clear leader if we total all the funerals. Counting the individual funeral entries alone, Midsummer leads with 29.3 per cent, followed by Easter with 25.6 per cent, Michaelmas with 24.5 per cent and Christmas with 20.5 per cent. If we 


\section{Mortality in fourteenth-century Exeter}

add the cumulative entries and count two for each, Midsummer goes further ahead with 35.8 per cent, Michaelmas remains about the same with 24.3 per cent, Easter falls a little lower to 23.3 per cent and Christmas lower still to 16.5 per cent. If we counted more than two for each cumulative entry, the positions of Midsummer and Christmas would be further exaggerated.

Comparing the annual figures for mortality at Exeter requires some caution, given that the records may have been kept with varying efficiency. In the most reliable period up to 1317 , two years stand out as low (1310-11) and three as high $(1312,1316-17)$. The first three (1310-12) seem to reflect local rather than national conditions, since Postan and Titow noted fairly high numbers of heriots on five southern English manors in 1310 (96) and 1311 (102), followed by a slight fall in $1312(84) .{ }^{17}$ There can be no doubt, however, that the very high Exeter mortality in the summers of 1316-17 reflects the general crisis caused in England by the two bad harvests of 1315 and $1316 .{ }^{18}$ During the two succeeding harvest-years, from the autumn of 1315 to the late summer of 1317 , commodities in southern England doubled in price ${ }^{19}$ and the price of wheat at Exeter (which is first recorded in 1316) rose steeply. In that year, it was 15.42 shillings per quarter, compared with a mean of 6.5 shillings during the following ten years. ${ }^{20}$ Such high figures for commodity and wheat prices were not to be recorded again until the 1540s. The famine was exceptional, and it was followed by widespread outbreaks of disease noted by contemporary writers as "pestilence" and "dysentery", leading to the deaths of "thousands" in different places. The wealthier inhabitants of Exeter were shielded by their wealth from the famine, but not from the diseases that it caused among their poorer neighbours. Similar effects have been noted elsewhere. Z. Ravi observes that in Halesowen, Worcs., the mortality spread to rich peasants in the prime of their lives, ${ }^{21}$ and Russell's figures for deaths among the aristocracy rise from a mean of forty-eight per annum between 1313 and 1315 to sixty-eight in 1316 and 62 in $1317 . .^{22}$

We now pass from the city to the smaller but better recorded community of the infirm priests of Clyst Gabriel. The priests' biographies show that they were mostly poor non-beneficed clergy of Devon and Cornwall, who had previously acted as hired curates or chantry priests until disabilities or advancing years made it impossible for them to read prayers and administer the sacraments. They seem to have ranged in age when they entered the hospital, between the thirties and the seventies, the largest number being apparently in their forties and fifties. Each priest was given lodging in the hospital dormitorium (presumably a communal room), $9 d$. a week for food, and $8 s$. a year for clothes; the weekly allowance was used to pay for meals cooked in the hospital kitchen. The premises and way of life appear to have been reasonably salubrious. As we shall see, several priests survived for many years after entry, and there were no major

${ }_{17}^{17}$ Postan and Titow, op.cit., note 3 above, Table 1.

18 On the crisis, see Kershaw, op.cit., note 4 above, pp.6-16.

${ }^{19}$ E. H. Phelps Brown and Sheila V. Hopkins, 'Seven centuries of the prices of consumables compared with builders' wage-rates', Economica, 1956, 311.

${ }^{20} \mathrm{Sir}$ W. H. Beveridge, 'A statistical crime of the seventeenth century', J. Econ. Business Hist. 1928-9, 1: 531 (a study of Exeter wheat prices).

${ }_{21} \mathrm{Z}$. Ravi, Life, marriage and death in a medieval parish. Economy, society and demography in Halesowen, 1220-1400, Cambridge University Press, 1980, p.40.

22 Russell (1966), op.cit., note 2 above, p.9. 


\section{N. Orme}

fatal epidemics in the place until the Black Death of 1349. The membership of the hospital is most fully documented between January 1312 and Michaelmas 1350, for which we possess accounts for all but seven of the years. The account of 1312 , however, is not as careful to indicate deaths as its successors, so we shall concentrate on the period between January 1313 and December 1348, before the Black Death started in the following month. During this pre-plague period of thirty-five years, ninety-two infirm priests are known to have entered the hospital: about fifteen short of the real total, due to the missing accounts. The entry of seventy-seven can be exactly dated, but that of the other fifteen only approximately. Sixty-one are stated to have died on an exact date, five to have withdrawn voluntarily, and eleven were still alive on 31 December 1348. The fate of the remaining fifteen is not recorded, again because of missing accounts, but presumably reflected the general pattern, i.e. nearly all died. Finally, forty-eight priests can be credited with exact dates both of entry and death before the end of 1348.

The expectation of life for these forty-eight when they entered the hospital, i.e. the mean interval between their entry and deaths, was three years and eleven months. The range of intervals, however, varied widely between two months and over nineteen years:

TABLE 2. PERIODS BETWEEN ENTRY AND DEATH AT CLYST GABRIEL

Years and months

$\begin{array}{cr}0.1-0.6 & 8 \\ 0.7-1.0 & 7 \\ 1.1-1.6 & 5 \\ 1.7-2.0 & 4 \\ 2.1-5.0 & 11 \\ 5.1 \text { and over } & 13\end{array}$

This range suggests that some of the priests were terminally ill when they entered, or responded badly to their new way of life, so that they died within a year (thirty-one per cent). Others were probably disabled - blind or crippled - and adjusted better, living for over five years (twenty-seven per cent). The remaining forty-one per cent came somewhere in between. The annual rate of deaths between 1313 and 1348 ranged between nil and four, with a mean of 2.3. Interestingly, there were four deaths in 1317, the second year of the great famine (the account for 1316 is missing), and four again in 1318. But unlike Exeter, the deaths of 1317 occurred in January, February, April, and October; none took place between July and September. The deaths were widely spaced within the years concerned, and there were never more than two in any two-month period. Totalling the deaths allows us to estimate the seasonal mortality, and here we shall continue to concentrate on the sixty-one priests who are known to have died between 1313 and 1348 . The monthly percentages are adjusted to take account of the number of days in each month: 
TABLE 3. SEASONAL MORTALITY OF PRIESTS AT CLYST GABRIEL, 1313-48

$\begin{array}{ccccccccccccc}\text { Months } & \text { Jan } & \text { Feb } & \text { March } & \text { Apr } & \text { May } & \text { June } & \text { July } & \text { Aug } & \text { Sept } & \text { Oct } & \text { Nov } & \text { Dec } \\ \text { Deaths } & 7 & 8 & 2 & 6 & 7 & 4 & 6 & 3 & 5 & 4 & 7 & 2 \\ \% & 11.2 & 14.1 & 13.2 & 9.9 & 11.2 & 6.6 & 9.6 & 4.8 & 8.3 & 6.4 & 11.6 & 3.2\end{array}$

The most fatal month was February, followed by January, May, and November to a roughly equal extent. The most fatal season was winter (December-February), accounting for 28.5 per cent of the deaths, followed by autumn (September-November) with 26.5 per cent, spring (March-May) with 24.3 per cent, and summer (June-August) with 21.0 per cent. It is, of course, advisable to regard these percentages cautiously, in view of the small size of the sample.

Up to 1348, deaths at Clyst Gabriel were compensated for by the entry of newcomers to take up the vacancies. But the Black Death changed all that. It struck the hospital soon after Christmas 1348, with such a clearly documented path that it is worth giving the exact dates to chart its course:

TABLE 4. DEATHS AT CLYST GABRIEL, 1 JANUARY 1348-29 SEPTEMBER 1350

$\begin{array}{clc}\text { Date } & \text { Death } & \text { Years and } \text { months in hospital } \\ \text { 18 Oct } 1348 & \text { John de Wyke } & 1.3 \\ \text { 1 Jan } 1349 & \text { Guy de Okampton } & 20.11 \\ \text { 2 Jan } 1349 & \text { Richard Artour } & 4.1 \\ 6 \text { Jan } 1349 & \text { Thomas de Well } & 14.2 \\ \text { 13 Feb } 1349 & \text { Adam de Axeminstre } & 1.8 \\ \text { 21 Feb } 1349 & \text { Thomas Putteford } & \text { Over } 8.5 \\ \text { 28 Feb } 1349 & \text { William de Luweneston } & 3.11 \\ \text { 1 March } 1349 & \text { Robert Sampson } & 5.10 \\ \text { 22 March } 1349 & \text { Walter de Reuwe } & 2.4 \\ \text { 27 March } 1349 & \text { Richard Molyns } & \text { Over } 8.5\end{array}$

There was then no death until

7 Feb 1350

Thomas Trebervet

6.0

Two comments can be made about these deaths. First, the mortality in the hospital between 1345 and 1348 had been lower than usual (five deaths in all, an annual mean of $1.2)$, so that a larger number of deaths in a single year was becoming increasingly likely. Richard Molyns was at least sixty years old, and Guy de Okampton had survived unusually long. On the other hand, the Black Death had equally fatal effects in able-bodied west-country communities. At Newenham Abbey, twenty-two miles east of the hospital, twenty out of twenty-three monks died, and at Bodmin Priory all but two out of about thirteen canons. ${ }^{23}$ Like many small religious houses, Clyst Gabriel

${ }^{23}$ G. Oliver, Monasticon Dioecesis Exoniensis, Exeter and London, 1846,p.364; F.C. Hingeston-Randolph (editor), The register of John de Grandisson, Bishop of Exeter, vol. 2, London and Exeter, 1897, p.1076. 


\section{N. Orme}

never fully recovered from this blow. With fewer unbeneficial clergy at work after the Black Death, it was less needed as a refuge for the disabled, and its roll dropped to between one and five infirm priests for the rest of its history. Accounts exist after 1350 , but fewer have survived and they cease to record the exact dates of entry and death, so that they cannot be used for demographic study. The hospital was eventually closed by the bishop in 1508 , and its possessions transferred to the vicars choral of Exeter Cathedral.

It remains to ask how the data from Exeter city and Clyst Gabriel relate to the evidence that has been collected about seasonal mortality elsewhere. The monthly figures nearest in date are those compiled by J. C. Russell from aristocratic land-holders before and after the Black Death of $1348-9,{ }^{24}$ and by J. Hatcher from the monks of Canterbury Cathedral between 1395 and 1505 . $^{25}$ The nearest three-monthly figures are those assembled by R. S. Gottfried from the inhabitants of Bury St Edmunds, $1354-1530,{ }^{26}$ and from testators of wills in eastern and south-eastern England between 1430 and $1480 .{ }^{27}$ In the latter case, separate figures are provided for various categories, including testators of both sexes, males, urban dwellers, and clergy:

TABLE 5. PERCENTAGES OF SEASONAL MORTALITY, 1340-1530

Dec Jan Feb March Apr May June July Aug Sept Oct Nov

\begin{tabular}{|c|c|c|c|c|c|c|c|c|c|c|c|}
\hline $\begin{array}{l}\text { Aristocracy } \\
1340-8\end{array}$ & 6.7 & 9.8 & 12.2 & 5.5 & 9.5 & 7.3 & 4.7 & 3.7 & 9.2 & 8.3 & 11.7 \\
\hline $\begin{array}{l}\text { Aristocracy } \\
1348-1500\end{array}$ & 7.0 & 5.9 & 7.3 & 7.8 & 6.6 & 7.7 & 7.1 & 6.9 & 11.8 & 13.7 & 9.9 \\
\hline $\begin{array}{l}\text { Monks } \\
1395-1505\end{array}$ & 7.5 & 6.7 & 9.1 & 7.9 & 5.0 & 6.0 & 5.8 & 9.0 & 12.4 & 12.6 & 11.5 \\
\hline $\begin{array}{l}\text { Bury St Edmunds } \\
1354-1530\end{array}$ & & 20.9 & & & 24.3 & & & 22.5 & & & 26.1 \\
\hline $\begin{array}{l}\text { All Testators } \\
1430-80\end{array}$ & & 24.2 & & & 26.8 & & & 19.6 & & & 29.4 \\
\hline $\begin{array}{l}\text { Male Testators } \\
1430-80\end{array}$ & & 24.1 & & & 26.5 & & & 19.6 & & & 29.7 \\
\hline $\begin{array}{l}\text { Urban Testators } \\
1430-80\end{array}$ & & 22.8 & & & 25.4 & & & 22.9 & & & 28.7 \\
\hline $\begin{array}{l}\text { Clerical Testators } \\
1430-80\end{array}$ & & 21.0 & & & 29.6 & & & 21.2 & & & 28.3 \\
\hline
\end{tabular}

The Clyst Gabriel figures, which are the more complete, have most in common with

${ }^{24}$ Russell (1948), op.cit., note 2 above, p. 197.

${ }^{25}$ Hatcher, op.cit., note 5 above, p. 26 .

${ }^{26}$ Gottfried, op.cit., note 16 above, p.66.

${ }^{27}$ R. S. Gottfried, Epidemic disease in fifteenth-century England, Leicester University Press, 1978, pp.109-113. 
those of the aristocracy, 1340-8. Both groups experienced the highest mortality in February, with January and November as other high months, though they differ in May (high at Clyst) and October (high among the aristocracy). Mortality took place to the same relatively high extent in winter in both groups, but among the aristocracy there was an even greater mortality in autumn, which affected the priests of Clyst much less. The latter, having their greatest mortality in the winter, differ from all the examples in Table 5: perhaps reflecting their age and disabilities, perhaps distorted by the smallness of the sample.

The funerals in Exeter are harder to place in context because the four terms of the Exeter accounting year are a month behind the seasons constructed by R. S. Gottfried. The Exeter figures resemble those of the post-Black Death aristocracy and monks in showing a peak of mortality in July-September, and share the same smaller levels in October-December, but Exeter displays more deaths in April-June and fewer in January-March. Compared with Gottfried's examples, Exeter appears to differ in showing the greatest period of mortality in summer rather than in autumn, but this difference probably results in part from the inclusion of September (a month of high mortality) in Exeter's summer and Gottfried's autumn figures. Early fourteenthcentury Exeter doubtless had a good deal in common with later-medieval and Tudor towns. It was not attacked by bubonic plague, which was particularly fatal in late summer and early autumn, but it must have experienced the enteric diseases caused by flies, poor sanitation, and starvation which were active in that season. The evidence from Exeter and Clyst Gabriel, however, is earlier in time than data from similar communities. Its true significance will only become clear when other urban and clerical sources have been studied, particularly from the pre-plague period. 